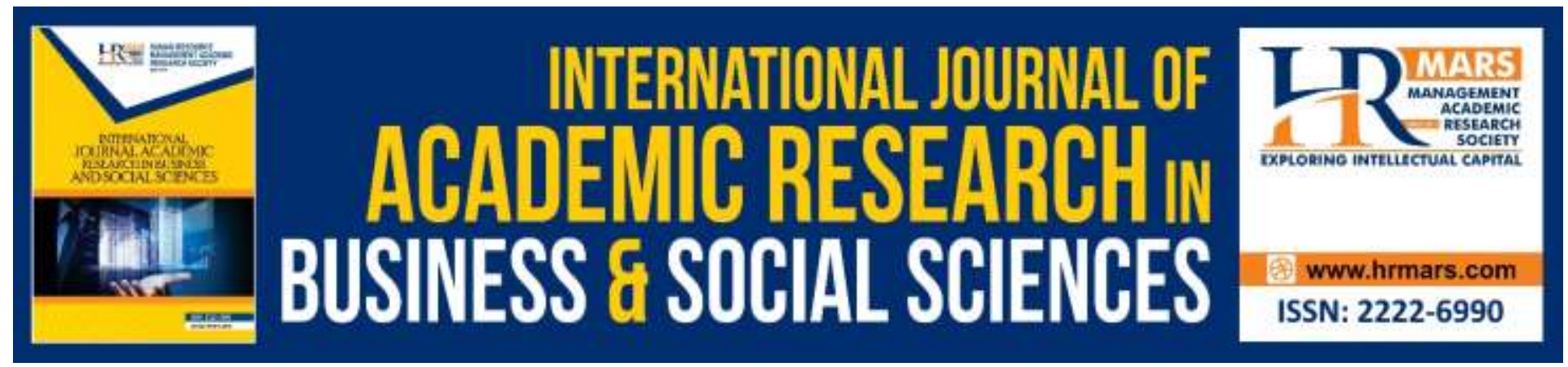

\title{
Applied Pattern of School Football Coaches' Coaching Process in Kuala Lumpur
}

Nazrul Fadzli Khairulhalimi \& Zulakbal Abdul Karim

To Link this Article: http://dx.doi.org/10.6007/IJARBSS/v10-i5/7186

DOI:10.6007/IJARBSS/v10-i5/7186

Received: 02 March 2020, Revised: 07 April 2020, Accepted: 16 April 2020

Published Online: 02 May 2020

In-Text Citation: (Khairulhalimi \& Karim, 2020)

To Cite this Article: Khairulhalimi, N. F., \& Karim, Z. A. (2020). Applied Pattern of School Football Coaches' Coaching Process in Kuala Lumpur. International Journal of Academic Research in Business and Social Sciences, 10(5), 179-190.

Copyright: (c) 2020 The Author(s)

Published by Human Resource Management Academic Research Society (www.hrmars.com)

This article is published under the Creative Commons Attribution (CC BY 4.0) license. Anyone may reproduce, distribute, translate and create derivative works of this article (for both commercial and non-commercial purposes), subject to full attribution to the original publication and authors. The full terms of this license may be seen

at: http://creativecommons.org/licences/by/4.0/legalcode

Vol. 10, No. 5, 2020, Pg. 179 - 190

http://hrmars.com/index.php/pages/detail/IJARBSS

JOURNAL HOMEPAGE

Full Terms \& Conditions of access and use can be found athttp://hrmars.com/index.php/pages/detail/publication-ethics 


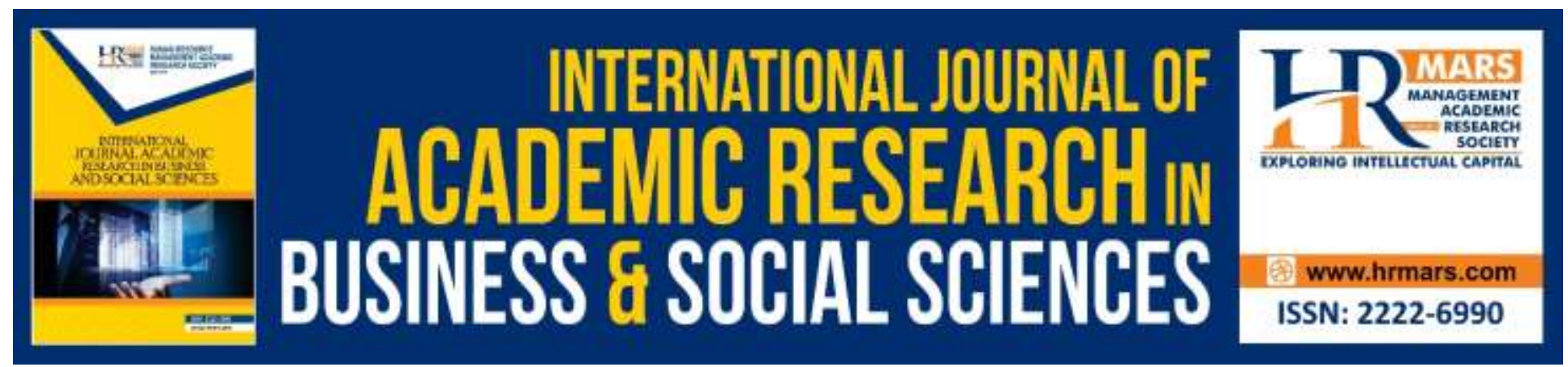

\title{
Applied Pattern of School Football Coaches' Coaching Process in Kuala Lumpur
}

\author{
Nazrul Fadzli Khairulhalimi \& Zulakbal Abdul Karim \\ Faculty of Sports Science and Coaching, Sultan Idris Education University, Tanjong Malim, Perak, \\ Malaysia \\ Email: nazsol83@yahoo.com,zulakbal@fsskj.upsi.edu.my
}

\begin{abstract}
This study aimed to explore the applied pattern of school football coaches' coaching process in Kuala Lumpur. 10 teachers also act as the football coaches and 11 school football players were the study participants and the number of participants were determined by the degree of saturation of information which is refer to no new information was discovered among the rest of the study participants (Lebar, 2017; Strauss \& Corbin, 1990). The data collection and the interview duration in this study was obtained 6 months through semi structured interview as suggested by Patton (2002). This study used qualitative research method called grounded theory approach as suggested by Strauss and Corbin $(1998,1990)$. The data were derived from the interview session and systematically collected, transcribed and analyzed by data analysis called coding which is consist of Open Coding, Axial Coding and Selective Coding (Strauss \& Corbin, 1998, 1990). Based on the findings of the study have shown there were six steps of football coaching process such as planning, pre-briefing, conduct training session, observation, coach and correct, post-briefing including training summary. At the end of the study, applied pattern of school football coaches' coaching process in Kuala Lumpur Model was successfully produced.
\end{abstract}

Keywords: Coaching Process, Coach, Football, School, Grounded Theory.

\section{Introduction}

Football is the popular sports for various ages started from kids until adult (Ali \& Talib, 2013). Football is considered as the number one sport in Malaysia and rest of the world based on television audiences, compared to other sporting events viewed (Karim \& Nadzalan, 2017; Karim, 2016; Hamid \& Kendall, 2008; Pundyk, 2004). Khoo Kay Kim (1994) stated that school is the best platform to produce talented athletes and the place that potential athletes equipped with proper training and guidance. This statement also stated in National Football Development Program (2014), school is one of the early education platform for physical activity related to 
football and basically teachers were the responsible person to teach and to coach the students in football.

There is nothing to discuss about sports coaching field (Karim \& Nadzalan 2017a; Karim \& Nadzalan, 2017b; Kjaer, 2017; Jones, Edwards \& Filho, 2016; Nelson, Cushion, Potrac \& Groom, 2014). Traditionally, coaching is defined as the existence of a coaching process by coaches that will drive the development of the athletes (Cushion, Nelson, Armour, Lyle, Jones, Sandford \& O'Callaghan, 2010). Maslovat and Franks (2008) stated coaching process can be described as the continuous cycle of any tournaments, competition and training session where coaches play their roles by observation and analyze the athletes' performance for the sake of their improvement.

Coaching process enable to assist in terms of coaches' education and development, can be acted as the catalyst in order to improve any fields, Abraham, Collins and Martindale (2006); Lyle (2002) to help coaches to provide the quality of experiences for athletes as well as the career development (Côté, Salmela, Trudel, Baria \& Russell, 1995). A coach needs to have the proper training guidelines because this is part of coaching science (Barnson, 2014). Therefore, this research has been conducted by exploring the applied pattern of school football coaches' coaching process in Kuala Lumpur and to produced the model of applied pattern of school football coaches' coaching process in Kuala Lumpur.

\section{Objectives}

- To see the efficacy of applied pattern of school football coaches' coaching process among coaches and football players' performance in Kuala Lumpur.

- To explore the existing applied pattern of school football coaches' coaching process in Kuala Lumpur.

- To build model of applied pattern of school football coaches' coaching process based on Grounded Theory Approach as suggested by Strauss \&Corbin $(2015 ; 1998)$.

\section{Literature Review}

Previous studies show that some researchers have been produced the coaching models that evolve from time to time for example "The Coaching Model" by Cote, Salmela, Trudel, Baria and Russels (1995). Abraham, Collins and Martindale (2006) have produced "The Coaching Schematic" which involved the decision-making process in the coaching process. Next coaching process model has been developed by Irvine (2012) regarding the "Analyze-Involve-Model (AIM) Soccer Coaching Process" which is based on three aspects such as process, behavior and leadership styles.

Cooper and Allen (2017) have applied semi structured interview to six coaches in order to explore the components of the applied coaching process through their study titled "The Coaching Process of the Expert Coach: A Coach Led Approach". Through the study of "The Coaching Process in Football - A qualitative perspective", Sarmento, Pereira, Anguera, Campanico and Leitao (2014) have interviewed eight football coaches from Portuguese League in order to explore the football coaching process. The eight football coaches possess 2 to 30 years of football coaching experiences. The study of "Understanding the Coaching Process : A Framework for Social Analysis" by Jones, Armour and Potrac (2002) based on the the 
exploration of coaching process in order to propose the coaching framework. Followed by these researches ideas came up for me to find the proper football coaching process in Malaysian School. Literature review is also vital in order to be referred for guidelines align with the study intent to explore the applied pattern of school football coaches' coaching process in Kuala Lumpur and to produce the model of it.

\section{Problem Statement}

Hamid and Kendall (2008) have stated Malaysia was formerly widely respected football team in Asian continent and still considered as the popular sport in this country. Although Malaysian football in the professional era but its performance still below the par and difficult to be proud of (Ali, 2016). As a result, the possibility to explore the football coaching process as one of the factors in performance achievement is needed.

National Football Development Program (2014) have reported that some problems have been raised before such as unqualified coaches and lack of technical or strategies knowledge issues including issue of qualified coaches but inexperienced to conduct training session at the grassroots level. There is possibility of some coaches do not take the coaching process seriously may be emerged. In addition, according to Sinar Harian (2014) have reported total of female teachers were $70 \%$ compared to male teachers and the possibility of unqualified coach will be emerged. Kuala Lumpur football achievement in tournament of Malaysian School Sports Council (MSSM) were not quite consistent from 2014 until 2019 for all categories such as Under 12 , Under 15 and Under 18 and mostly at grouping level.

Karim and Nadzalan (2017a); Karim and Nadzalan (2017b) have stated that football coaches in this country may face some obstacles such as education curriculum, career path of the coaches' issue, limited opportunities including career assurance as a coach. Thus, this study was conducted in order to explore the competency of the football coaches in conducting football coaching process at school in Kuala Lumpur.

\section{Research Methodology}

This study has applied Grounded Theory Approach as suggested by Strauss and Corbin (1998, 1990) and coding method have been used for data analysis purpose. Basically, the coding consists of Open Coding, Axial Coding and Selective Coding. Strauss and Corbin (1990) have stated the data collection and data analysis were the integrated process. This term also called as "interplay in nature" which researchers responded to the data (Strauss \& Corbin, 1998). Strauss and Corbin also stated through Grounded Theory, which the analysis will begin shortly after the first data is collected. There were 1,326 coding identified in this study using the open coding procedure. The analysis of interview transcripts was carried out with line-by-line analysis to identify the potential themes and concepts in the data. The data collection method in this study consists of semi-structured interview, observation and documentation analysis as suggested by (Marshall \& Rossman, 2006; Creswell, 1998; Strauss \& Corbin, 1998). The findings of the study were transcribed and analyzed by using coding method. The preliminary analysis is vital because it enable to guide the upcoming interview and observation session (Strauss \& Corbin, 1990). 


\section{Research Concept Framework}

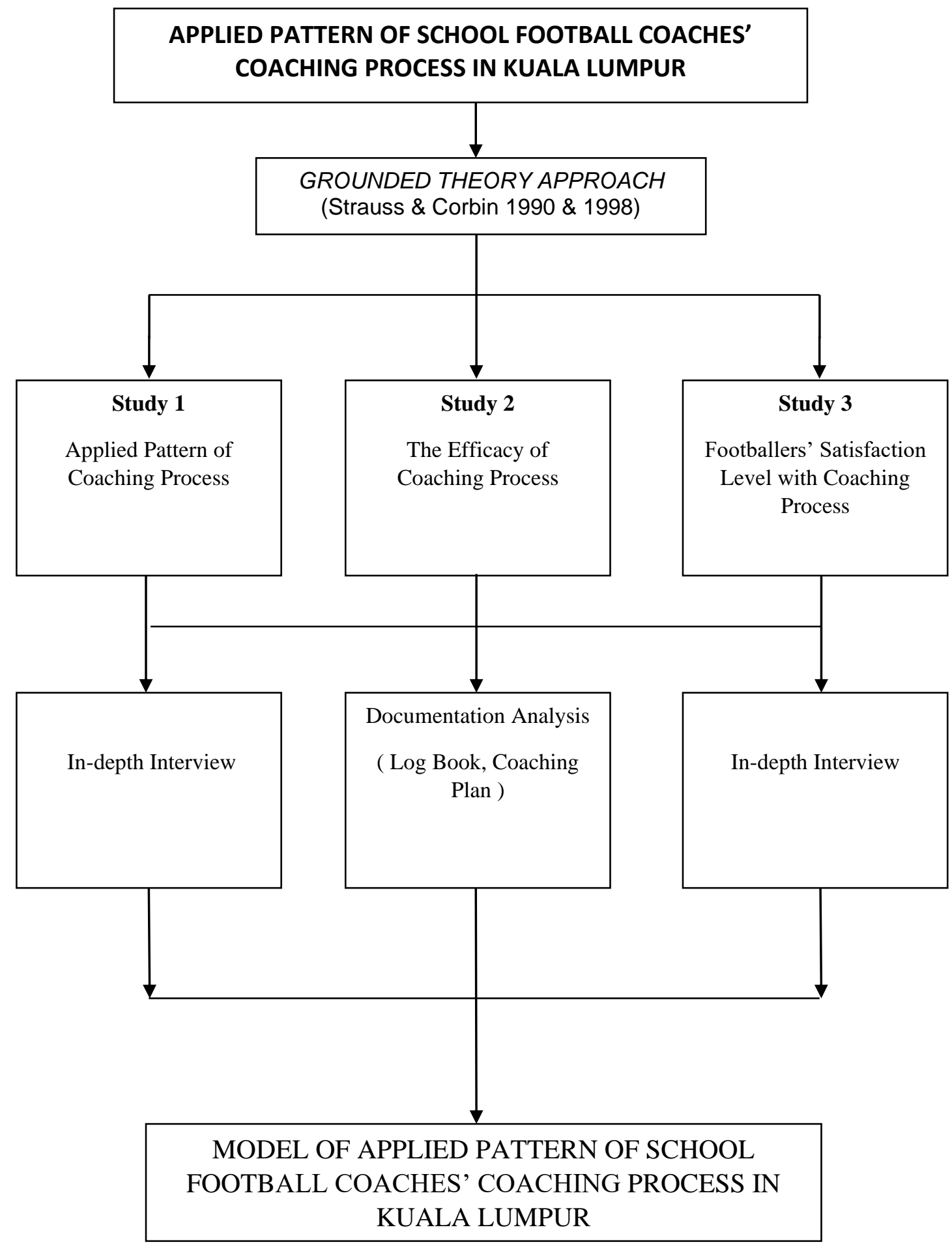

Rajah 1.1: Research Concept Framework 


\section{Sample}

Purposive Sampling or Judgement Sampling has been used in this study where the researchers rely on self-assessment when choosing among population to participate in this research (Black, 2010). Black (2010) also stated purposive sampling is a non-probability sampling method and it occur when the elements selected for sampling purposes. In a nutshell, the researchers will decide what to explore and assigned in order to select participants who are willing to provide information based on their knowledge and experience (Bernard, 2002).

A total of 10 teachers cum football coaches and 11 school football players were selected for the interview session. These coaches were equipped football coaching license from $D$ level to $B$ level and possess vast experience in football coaching. The selections of 11 school football players were made in order to explore the satisfaction level of football players with coaching process.

During interview session, numbers of participants were determined by the degree of saturation of information which no new data seem to be emerged compared to the rest of the previous participants (Lebar, 2017; Strauss \& Corbin, 1998; Glaser \& Strauss, 1967).

\section{Data Collection}

Semi-structured interview has been used in this study to all participants including 10 teachers cum football coaches and 11 school football players at school in Kuala Lumpur accordingly to Creswell (2013); Patton (2002) the researchers need to establish the trustworthy with the participants and determine the open-ended questions. The answers must be recorded by tape in great details, to expand the unstructured ideas Gibbs and Taylor (2005) as well as exploring the participants' views and experiences. Align with the study objectives, the researcher has used the semi-structured interview format because it contains a set of open-ended questions that consist of demographic information, experiences and perceptions of the participants (Creswell, 2013; Patton, 2002; Merriam (2001). The interview session was transcribed and analyzed by using Grounded Theory Approach (Strauss \& Corbin, 1998).

Bogdan and Biklen (2003); Esterberg (2002); Kvale (1996) also stated a set of open-ended questions is able to get feedback publicly. Apart from interview session, the observation can be made in order to observe the involvement of coaches and players in football coaching process (Karim \& Nadzalan, 2017; Karim et al., 2018; Karim, Ghafar, \& Nadzalan, 2018). A few numbers of documents such as log book and periodization were collected for the documentation analysis purpose.

\section{Data Analysis}

This study was conducted by using Grounded Theory Approach by Strauss and Corbin (1998, 1990). For data analysis purposes, coding method have been applied. Coding method consists of Open Coding, Axial Coding and Selective Coding are the practice of researchers who using Grounded Theory Approach (Strauss \& Corbin, 2015; 1998; 1990). 


\section{Open Coding}

A total of 1,326 open coding successfully produced in this study. The interview was transcribed with line-by-line analysis in order to identify the potential codes, themes and concepts at the preliminary stage of Open Coding. Axial Coding and Selective Coding were later used in order to produce theory or model in an inductive process (Strauss \& Corbin, 1990).

\section{Axial Coding}

Strauss and Corbin (1998) have recommended Axial Coding is "a set of procedures whereby data are put back together in new ways after open coding, by making connections between categories". Strauss and Corbin (1998) have stated central category have to be identified and linking all the categories by using selective coding.

\section{Selective Coding}

Once the core variables have been determined, selective coding must be applied. The interview guides and procedures were used with these 10 coaches and 11 school football players at school in Kuala Lumpur and the core categories were identified from the data analysis.

\section{Results}

All 10 teachers cum football coaches have shared six steps of football coaching process such as planning, pre briefing, conduct training session, observation, coach and correct, post briefing including summary. Overall, the 11 school football players in Kuala Lumpur have satisfied with the football coaching process that was conducted by their coach and through football coaching process have impacted the football players' performance. In a nutshell, applied pattern of school football coaches' coaching process in Kuala Lumpur is vital to be implemented every football training session because it is one of the coaches' competencies, requirement in training session and can give positive implications towards football players' performance.

\section{Discussion}

Model of applied pattern of school football coaches' coaching process in Kuala Lumpur was successfully produced through the data analysis. The main theme in this research is characteristic for school football coaches which consist of three sections such as demography, challenges and competency. Finally, the six steps of football coaching process such as planning, pre briefing, conduct training session, observation, coach and correct, post briefing including summary have been produced. Model of applied pattern of school football coaches' coaching process in Kuala Lumpur was successfully produced through data analysis shown Figure 1.2 as below. 


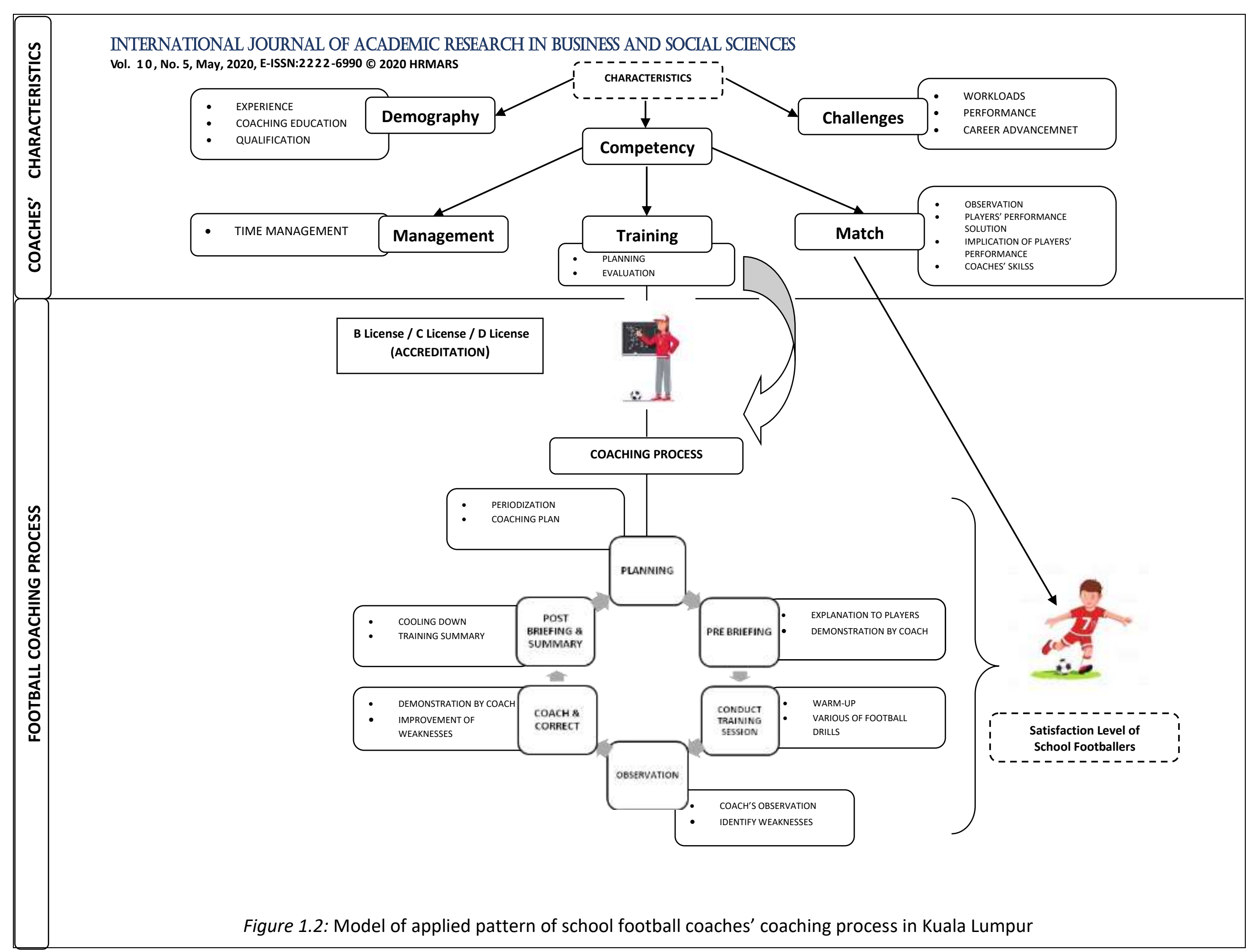




\section{Conclusion}

Coaching process is one of the coaches' competencies. According to Martens (2002), football coaching process is vital because football coach is the responsible person for his team and has the goal of improvement and empowerment of the players' performance. Mallett and Dickens (2009) have stated the coaches play the vital role not just to produce athletes but to ensure they were equipped with knowledge and highly skilled in any respective sports. Based on the research findings have shown there were six steps of football coaching process such as planning, pre briefing, conduct training session, observation, coach and correct, post briefing including summary. From the aspect of coaches' planning, all coaches need to have their own periodization or coaching plan. Aspect of pre briefing has shown the explanation of training session to all football players including demonstration by coaches. For conducting training session, warm-up will start first before proceed to further various types of drills. In observation, the coaches need to see how well the training session run and can identify players' strength and weaknesses. And then, aspect of coaching coach shown the coaches will demonstrate to the players in order to improve any respective weaknesses. Finally, the football coaching process will be ended with post briefing and summary by coaches, start with cooling down of players and coaches will summarize the training session to them accordingly. The football governing body should re-look at the training syllabus of coaches in order to include the coaching process. Thus, they will be trained with current characteristics' demands and needs of the coaches have learned from the ground.

\section{Suggestion}

It is recommended that the future researchers who tend to conduct research regarding football coaching process to be expanded in other states besides Kuala Lumpur. Through this research, it is hoped that the model of applied pattern of school football coaches' coaching process in Kuala Lumpur will be considered to be the blue print at school level in order to ensure the standardization of applied pattern of football coaching process.

Ethical clearance - The study has been done in accordance with human research ethics as per required by the Declaration of Helsinki.

\section{References}

Abraham, A., Collins, D., \& Martindale, R. (2006). The coaching schematic: Validation through expert coach consensus.Journal of Sport Sciences, 24(6), 549-564.

Ali, A., \& Taib, M. D. (2013). Siri sukan popular bola sepak. Shah Alam: Oxford Fajar.

Ali, M.F.M. (2016). Biomekanik Dalam Sukan Bola Sepak Di Malaysia. Universiti Malaysia Kelantan, Faculty of Creative Technology and Heritage, 16300 Bachok, Kelantan Darul Naim, Malaysia.

Barnson, S. (2014). The authentic coaching model: a grounded theory of coaching. International Sports Coaching Journal, 1, 61-74.

Bernard, H. R. (2002). Research methods in anthropology: Qualitative and quantitative approaches (3rd ed.). Walnut Creek, CA: Alta Mira Press.

Black, K. (2010) "Business Statistics: Contemporary Decision Making" $6^{\text {th }}$ edition, John Wiley \& Sons. 
INTERNATIONAL JOURNAL OF ACADEMIC RESEARCH IN BUSINESS AND SOCIAL SCIENCES Vol. 10, No.5, May, 2020, E-ISSN:2222-6990 @ 2020 HRMARS

Bogdan, R. C. \& Biklen, S. K. (2003). Qualitative research for education. An introduction to theory and methods ( $4^{\text {th }}$ ed.). Boston, MA : Allyn and Bacon.

Creswell, J. (2013). Qualitative inquiry \& research design: Choosing among five approaches (3rd ed.). Thousand Oaks, CA: Sage Publications, Inc.

Creswell, J. W. (1998). Qualitative inquiry and research design: choosing among five traditions. Thousand Oaks CA.: Sage Publications.

Cushion, C., Nelson, L., Armour, K., Lyle, J., Jones, R., Sandford, R., \& O'Callaghan, C. (2010). Coach learning and development: A review of literature. Leeds: sports coach UK.

Cooper, D., \& Allen, J. B. (2017). The coaching process of the expert coach: A coach led approach. Sports Coaching Review.

Corbin, J., \& Strauss, A. (2015). Basics of Qualitative Research: Techniques and Procedures for Developing Grounded Theory (4th ed.). Thousand Oaks, California: Sage.

Côté, J., Salmela, J., Trudel, P., Baria, A., \& Russell, S. (1995). The coaching model: a grounded assessment of expert gymnastic coaches' knowledge. Journal of Sport and Exercise Psychology, 17, (1), 1-17.

Creswell, J. (2013). Qualitative inquiry \& research design: Choosing among five approaches (3rd ed.). Thousand Oaks, CA: Sage Publications, Inc.

Esterberg, K. G. (2002). Qualitative methods in social research. Boston, MA : McGraw-Hill.

Glaser, B. G., \& Strauss, A. (1967). The discovery of grounded theory: strategies for qualitative research. Chicago, III: Aldine Pub. Co.

Gibbs, G. R., \& Taylor, C. (2005). How and what to code. Retrieved from http://onlineqda.hud.ac.uk/Intro_QDA/how_what_to_code.php

Hamid, N. H. A., \& Kendall, G. (2008). Maximizing stadium attendance: A case study of Malaysian football. Proceedings of the 7th International Conference on the Practice and Theory of Automated Timetabling PATAT (pp. 1-4). Montreal: Université de Montréal.

Harian, S. (2014). Seimbangkan guru lelaki dan wanita. Retrieved from http://www.sinarharian.com.my/karya/pendapat/seimbangkan-guru-lelaki-wanita1.269857

Irvine, R. (2012). "The Analyze-Involve-Model (AIM) Soccer Coaching Process" Master of Science in Organizational Dynamics Theses. 53. http://repository.upenn.edu/od_theses_msod/53

Jones, R. L., Armour, K. M., \& Potrac, P. (2002). Understanding the coaching process: A framework for social analysis. Quest, 54(1), 34-48.

Jones, R. L., Edwards, C., \& Viotto Filho, I. T. (2016). Activity theory, complexity and sports coaching: An epistemology for a discipline. Sport, Education and Society, 21(2), 200-216.

Karim, Z. A. (2016). Malaysian football coaches: The key challenges. International Journal of Health, Physical Education and Computer Science in Sports, 24(1), 18-24.

Karim, Z. A., \& Nadzalan, A. M. (2017a). The development of coaching knowledge among Malaysian accredited football coaches. International Journal of Academic Research in Progressive Education and Development, 6(4), 113-127. 
INTERNATIONAL JOURNAL OF ACADEMIC RESEARCH IN BUSINESS AND SOCIAL SCIENCES Vol. 10, No.5, May, 2020, E-ISSN:2222-6990 @ 2020 HRMARS

Karim, Z. A., \& Nadzalan, A. M. (2017b). Malaysia Football Coaches:

Development Characteristics. International Journal of Academic Research in Business and Social Sciences, 7(9), 305-312.

Karim, Z. A., Razak, A. N. A., \& Nadzalan, A. M. (2018).

Designing model of career path development for National Football Development Program (NFDP): directions, issues, challenges and sources of knowledge that influence and develop coaching expertise level. International Journal of Academic Research in Business and Social Sciences, 8(3), 542-550.

Karim, Z. A., Ghafar, N. A. A., \& Nadzalan, A. M. (2018). The leadership style among football coaches leadership style among teachers in Hulu Langat district: The implications on National Football Development Program (NFDP) in Malaysia. International Journal of Academic Research in Business and Social Sciences, 8(3), 551-558.

Khoo, K. K. (1994). Sekitar Sukan Malaysia. Berita Minggu May, 31. (1994). Sekitar Sukan Negara. Sekolah Berfungsi Lahirkan Bakat Sukan.

Kjaer, J. B. (2017). Preparing Sports Coaches for the 21st Century: A Qualitative Case Study of A Graduate Sports Coaching Education Program. Pro Quest LLC.

Kvale, S. (1996). Interviews: An introduction to qualitative research interviewing. Thousand Oaks, CA: Sage Publications.

Lebar, O. (2017). Penyelidikan Kualitatif: Pengenalan Kepada Teori dan Metode Edisi Kedua. Tanjung Malim: Universiti Pendidikan Sultan Idris.

Lyle, J. (2002). Sports coaching concepts: A framework for coaches' behaviour. London and New York: Routledge.

Mallett, C. J., \& Dickens, S. (2009). Authenticity in formal coach education: Online postgraduate studies in sports coaching at The University of Queensland. International Journal of Coaching Science, 3(2), 79-90.

Marshall, C., \& Rossman, G. B. (2006). Designing Qualitative Research (4 th ed.). Thousand Oaks, Calif: Sage Publications.

Martens, R. (2002). El Entrenador de Éxito. Barcelona: Editorial Paidotribo.

Maslovat, D., \& Franks, I. M. (2008). The need for feedback. In M.D. Hughes, \& I.M. Franks (Eds.), The essentials of performance analysis: An introduction (pp. 1- 7). London: Routledge.

Merriam, S.B. (2001). Qualitative Research and Case Study Applications in Education. San Francisco: Jossey-Bass Pub.

Nelson, L., Cushion, C. J., Potrac, P., \& Groom, R. (2014). Carl Rogers, learning and educational practice: Critical considerations and applications in sports coaching. Sport, Education and Society, 19(5), 513-531.

Patton, M. Q. (2002). Qualitative research and evaluation methods 3rd ed. Thousand Oaks, CA: Sage.

Pundyk, G. (2004). Welcome to Malaysia. Singapore: Times Editions.

Sarmento, H., Pereira, A., Anguera, M., Campaniço, J., \& Leitão, J. (2014). The Coaching Process in Football - A qualitative perspective. Montenegrin Journal of Sports Science and Medicine, 3(1), 9-16.

Strauss, A., \& Corbin, J. (1990). Basics of Qualitative Research Grounded Theory 
INTERNATIONAL JOURNAL OF ACADEMIC RESEARCH IN BUSINESS AND SOCIAL SCIENCES

Vol. 10, No.5, May, 2020, E-ISSN:2222-6990 @ 2020 HRMARS

Procedures and Techniques. Newbury Park: Sage Publications

Strauss, A., \& Corbin, J. (1998). Basics of qualitative research techniques and procedures for developing grounded theory. Second edition Thousand Oaks: Sage Publications.

\section{Corresponding Author}

Nazrul Fadzli Bin Khairulhalimi

Faculty of Sports Science and Coaching

Sultan Idris Education University, Tanjong Malim, Perak, Malaysia

Email:nazsol83@yahoo.com 